\title{
FINANCIAL SUPPORTING TOOLS OF RURAL TOURISM DEVELOPMENT IN NITRA SELF-GOVERNING REGION
}

\author{
Jana Jarábková, L’ubica Majstríková, Tomáš Kozolka ${ }^{1}$
}

Received 21 March 2016; Accepted 30 June 2016

\begin{abstract}
Rural tourism is one of the opportunities, which can positively influence productivity and incomes in rural areas. European Union set the rural development as part of its priorities. This development has been conducted through several measures aimed at education, cooperation, municipality development, ecological agriculture, diversification of economic activities, etc. Rural tourism is a result of diversification of economic activities towards non-agricultural activities. The paper focuses on analysing financial tools of support used for rural tourism development. Development projects realized in the Nitra Self-governing Region (NSR) during programming period $2007-2013$ (plus 2 years) are evaluated. These projects have been financed through different grant schemes created by the European Union (realised by Ministries, Local Action Groups, Agricultural Paying Agency) and also by the Nitra Self-governing Region. The paper also illustrates the localisation of approved projects and their purpose.
\end{abstract}

Key words: Rural tourism, financial tools, support, Nitra Self-governing Region

\section{Introduction}

Several authors consider rural tourism² (Lane B., 1994, Galvasová G., 2008, Humaira I., 2010, Özdemir G., Kiper T. 2012, Tej J., Matušíková D., 2014) as an economic activity positively influencing municipal development in economic, social, cultural and environmental fields. Therefore, rural tourism support had become important tool of rural development policy at the European level in 90 -ties of $20^{\text {th }}$ century.

Within the Rural Development Policy of European Union (EU), the rural tourism has been understood as a tool for diversification of economic activities in rural areas and as a way how to improve the quality of life in rural areas. Objectives and priorities of European rural development policy were reflected into national policies of a particular EU member state. In 2007 there was created a source for financing of rural tourism policy - European Agriculture Fund for Rural Development (EAFRD).

\footnotetext{
1 Doc. Ing. Jana Jarábková, PhD., Ing. L'ubica Majstríková, Ing. Tomáš Kozolka, Department of Regional Studies and Rural Development, Faculty of European Studies and Regional Development, Slovak University of Agriculture in Nitra, Andreja Hlinku 2, 94976 Nitra, Slovak Republic; e-mails: jana.jarabkova@uniag.sk, I.majstrikova@gmail.com, kozolka.tomas@gmail.com

${ }^{2}$ For the purpose of the paper, rural tourism is considered as a form of tourism including all activities realized by visitor in rural area.
} 
The Slovak Republic declared targeted support for rural tourism from 1992, by the statement of the Departmental Support Program for Rural Tourism, Agro and Forest Tourism of the Ministry of Agriculture SR. The aim of the departmental program was to support business activities (focused on tourism) of agricultural enterprises. Already at that time, alternative activities that would help to stabilize the business activity, production and employment of farms were considered. The idea to support the diversification of originally mono-structural economic base of rural areas through different activities, including tourism, was reflected in aims and priorities of rural development policy in the following period. The support of rural tourism as a tool for diversification of economic activities in rural areas was taken into account in key strategic documents forming rural development policy - in the Concept of Rural Development (1998), the Development Plan of Agricultural and Rural Areas SR (2000), the Rural Development Plan for Period 2004 - 2006, the Rural Development Programme 2007 - 2013. Measures aimed at rural tourism support are also part of the new concept of the rural development policy for period 2014 - 2020 (Rural Development Programme 2014 - 2020).

The European Commission allocated 90.8 billion $€$ for rural development in the period 2007 2013 and $2.17 \%$ of this amount for support of rural areas in SR.

Rural tourism, at the national level, is also supported within sectoral policy - tourism policy. Support tools are focused on increasing competitiveness of tourism industry with better use of potential, on balancing regional disparities and on creation of new job opportunities. Rural tourism, in frame of aims of tourism policy, is mostly perceived as one of "friendly" tourism forms and particularly supported activities, which are typical for stay in the rural areas: agritourism, cycling and ecotourism. This tourism policy is mostly oriented on meeting the "sectoral" defined priorities, without particular reference to the territorial (spatial) principle; it means, in implementation of tools, it does not take into account specific rural environment. Priorities and measures of state tourism policy in 2007 - 2013 were aimed at increasing of competitiveness of tourism industry generally, employment support and business, and promotion support in this sector.

Self-governing region is responsible for tourism policy at regional level. It formulates objectives of this policy in strategic documents, usually in regional strategy of tourism development in particular period. It can use the whole complex of tools to fulfil these objectives. In terms of the nature, objectives can be divided into two groups: financial and non-financial (Wokoun, Mates, 2006).

\begin{tabular}{|c|c|}
\hline Financial tools & Non-financial tools \\
\hline $\begin{array}{c}\text { Non-investment and investment } \\
\text { instruments (subsidies, grants, loans and } \\
\text { bank guarantees) }\end{array}$ & $\begin{array}{c}\text { Administrative tools (legislation and drafting of } \\
\text { generally building regulation), }\end{array}$ \\
\hline Capital co-partnership & $\begin{array}{c}\text { Institutional tools (regional and local strategic } \\
\text { documents and development plans of higher } \\
\text { territorial units and municipalities), }\end{array}$ \\
\hline Tax allowance (tax holiday or tax rate \\
reduction)
\end{tabular}

Tab 1. Tools of public sector for rural tourism support. Source: GALVASOVÁ, l.; et.al. 2008. Průmysl cestovního ruchu. Praha: Ministerstvo pro místní rozvoj ČR., 2008, own processing, 2015

Administrative tools create basic framework for the functioning of the tourism sector. Elaboration and implementation of legislation in the field of tourism is the responsibility of the state. At the regional level, regional self-government can use comparable tools, generally binding regulations that can help to fulfil objectives of the tourism policy (rural tourism policy). An example of generally binding regulations applied in the practice are supporting mechanisms for financing of business activities in tourism (financed from the regional budget) - grant or subsidy schemes, support of redevelopment of regional cultural-historical potential, support of 
the quality growth of tourism services or support of strategy documents formulation in tourism in the micro-regions. Institutional tools belong also among the important non-financial tools used by regional self-government in the coordination of tourism activities. The most significant institutional tool is strategic planning, resulting into the formulation of strategic (conceptual) documents and its implementation in the practice. Initiation of organisational structures, which should fulfil specific tasks in tourism development, can also by part of the implementation process. The examples of such organisational structures at the regional level are regional and territorial organisations of tourism. According to Act No. 91/2010 Coll. on the tourism support, the role of regional organisations of tourism is to cooperate in formulation and implementation of tourism concept in the region, to support activities of its members, particularly in marketing, to create tourism products, to participate in the organisation of events for visitors, to support cultural, social and sport life in its territory and to promote sustainable tourism.

According to Galvasová et al. (2008) non-financial support of tourism development is not defined only to coordinate the development process, development of organisation structures, but it also includes variety of other non-financial tools, such as information and methodological support, subject support, marketing, networking, creating partnerships, etc. Gúčik (2010) adds also advisory, education and consulting services for small and medium enterprises.

Usage of non-financial tools for support of tourism development in the practice is necessarily linked to exploitation of financial tools. Typical financial tools used in tourism policy are subsidies (grants) ${ }^{3}$ and advantageous loans and guarantees. Subsidies to support tourism activities can be distinguished depending on the purpose of use, beneficiary, provider, amount of subsidy, eligibility to allocation, financing expenses, necessity for co-financing, etc. Sources of the subsidy are state budget, state extra budgetary funds, EU budget, regional budgets, municipal budgets or funds of other subjects. Maráková (2005) and Gúčik (2010) considered that credit and guarantee development programmes are also important financial tools for tourism development in Slovak conditions. The objective of credit programmes with advantageous conditions is to allow access to financial capital for tourism enterprises. Guarantee programmes are formed by commitment of natural person or corporate body for another subject - e.g. state guarantees for entrepreneur and it means that his project will become more interesting for investors and less risky.

European and investment funds (European Regional Development Fund (ERDF), European Social Fund (ESF), European Agriculture Fund for Rural Development (EAFRD)) are particularly interesting for entities from the Slovak Republic in terms of the volume of financial resources available for tourism support.

\footnotetext{
${ }^{3}$ Subsidies are non-repayable funds that do not require "consideration" and are provided from public funds. They are designed to support specific activity or group of activities.
} 


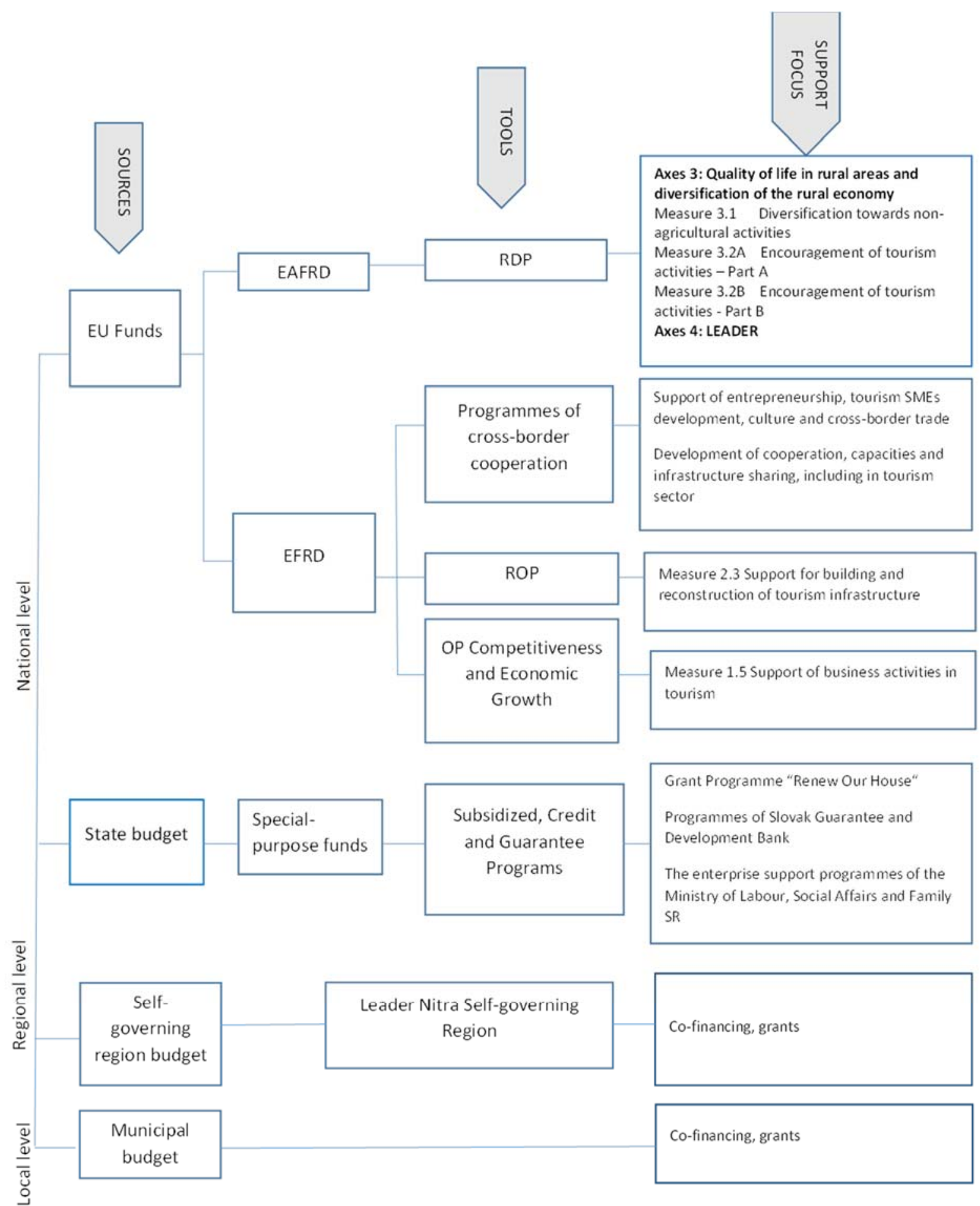

Fig 1. Possibilities of financial support for rural tourism in Slovakia in the period 2007 - 2015. Source: own processing, 2015

\section{Objective, Sources and Data Processing}

The objective of the paper is to analyse the use of financial tools for support of rural tourism development in the Nitra Self-governing Region (NSR) in the period 2007 - 2015 by focus of supported activities, beneficiaries and financial resources of subsidies in view of the location. Within the paper we have focused on the financial support of rural tourism through subsidies that were aimed at supporting entities with place of business in rural areas of the Nitra Selfgoverning Region. The support was directed to three types of entities: 
- private sector - enterprises operating in rural tourism with the seat in a rural municipality located in the territory of the Nitra Self-governing Region,

- public sector - municipalities without status of town,

- non-profit sector - civil associations, local action groups, foundations, non-profit organisations providing public services.

Following funds were identified as significant sources of support for rural tourism in the Nitra Self-governing Region during the period 2007 - 2015: European Agriculture Fund of Rural Development (EAFRD), European Fund for Regional Development (ERDF) and budget of the Nitra Self-governing Region. The purpose of the aid, in the form of subsidies, is related to rural development policy, Tourism policy in SR and especially in the Nitra Self-governing Region at the regional level. Therefore, we will also follow the purpose of allocated subsidies (Table 2).

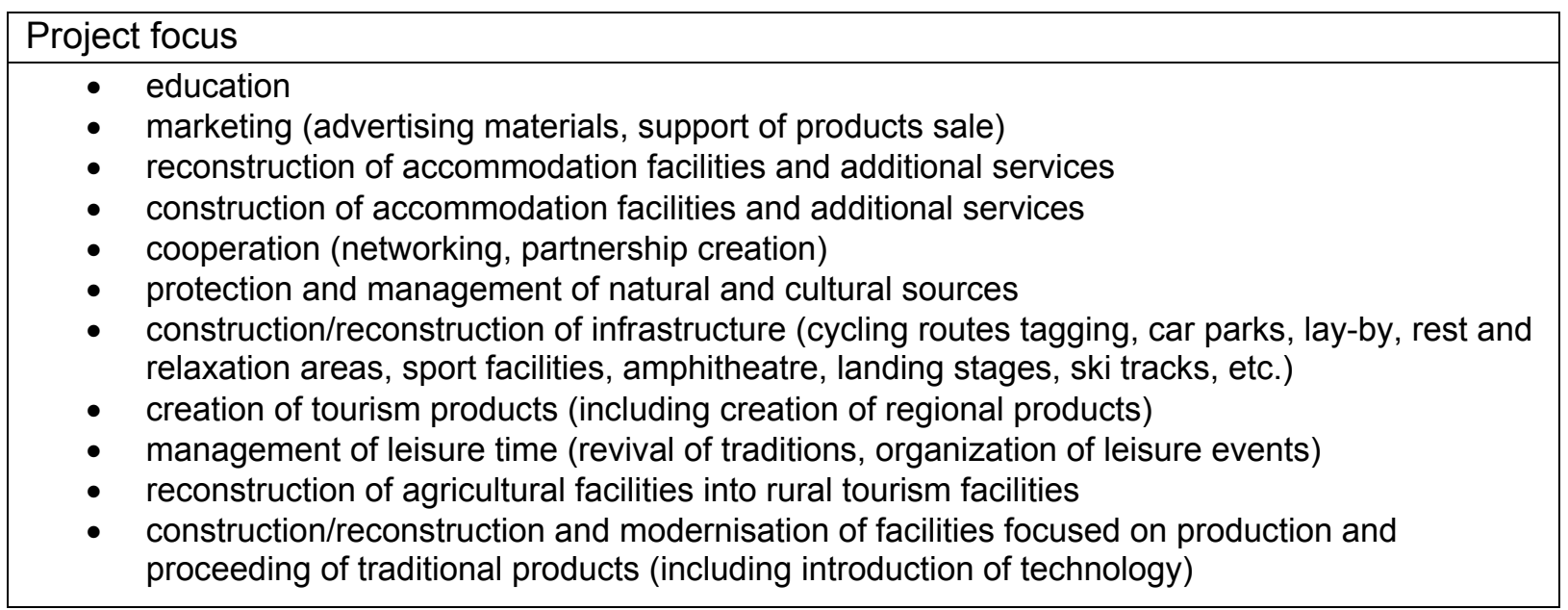

Tab 2. The distribution of projects by purpose of grants. Source: own processing, 2015

The use of subsidies to support rural tourism is also evaluated from special point of view. The objective is to identify the intensity of drawn support funds by the municipalities and the spatial distribution of allocated funds. Software ArcGIS was used for spatial analysis of data.

We analysed published data from Agricultural Paying Agency, Ministry of Agriculture and Rural Development SR and the Office of the Nitra Self-governing Region.

\section{Assessment of Selected Financial Supporting Tools of Rural Tourism Development in the Nitra Self-governing Region in the Period 2007 - 2015}

\section{a) Nitra Self-governing Region and Its Potential for Rural Tourism}

Nitra Self-governing Region (NSR) with its territory $6,343.8 \mathrm{~km}^{2}$ covers $13 \%$ of the area of the Slovak Republic. It is located in southwest part of the Slovak Republic and it shares border with Hungary to the south, with Banská Bystrica Self-governing Region in the east, with Trenčín Self-governing Region in the north and with Trnava Self-governing Region in the west. According to the territorial-administrative division, it is divided into seven districts: Komárno, Levice, Nitra, Nové Zámky, Šal'a, Topol'čany and Zlaté Moravce.

Relief of the region has mostly flat and lowland character. Carpathian Mountains marginally extend to the Nitra Self-governing Region with its parts: Považský Inovec, Tribeč, Pohronský Inovec, Štiavnické vrchy, Krupinská planina and Burda. A substantial part of the south and southeast of region takes agricultural land. The region is one of the warmest areas and one of the most productive agricultural centres of SR. The region, particularly its southern areas, is rich in the occurrence of water resources. Nitra Self-governing Region is the fifth biggest region in SR. It is the fourth most populated region of SR with 686,662 inhabitants (December 31, 2013) and the share of total population of SR is $12.7 \%$ Population density is 108.2 inhabitants $/ \mathrm{km}^{2}$ what is slightly below the Slovak average $\left(110\right.$ inhabitants $\left./ \mathrm{km}^{2}\right)$. There are 354 municipalities in 
the Nitra Self-governing Region, while 15 of them have the town status. Population living in rural area represents $54.2 \%$ of overall regional population.

In term of evaluating the conditions for rural tourism development within the Regionalisation of Tourism in SR, NSR has suitable conditions for development of rural tourism activities. The Strategy of Tourism Development of NSR for the Period 2007 - 2013 identified rural tourism as an important part of tourism product portfolio and the Strategy of Rural Development of NSR for the Period 2009 - 2015 identified rural tourism as a tool for job creation in rural development using internal resources.

\section{b) Results and Discussion}

Financial support of rural tourism in the period 2007 - 2013 was focused on enterprises, municipalities, micro-regions and non-profit sector. It was supported from several financial resources, such as the EU funds (ERDF, EAFRD), state special-purpose funds and regional budget at the regional level (Figure 1). Based on the monitored financial tools and resources we it can be said that rural tourism was supported in 158 municipalities of the Nitra Self-governing Region by different intensity (47\% rural municipalities).

The amount of support in 33 municipalities reaches more than 100,000 € per 1,000 inhabitants. Regarding the amount of placed funds divided according to the focus of the project, the highest share of finances between the years 2007 - 2015 was used for projects focused on construction of small capacity accommodation facilities in the rural areas including construction of facilities providing additional services in rural tourism ${ }^{4}$. The volume of funds allocated for this purpose amounted nearly $73 \%$ of the total funds for the support of rural tourism in the NSR. These projects were also supported by the highest amount from public funds - 1 project was supported by $220,908 €$ in average.

Beneficiaries were only from the private sector. Significant differences in financing of these investment activities were observed in the use of support resources. The main source of financing the construction of accommodation facilities and facilities with additional services is the European Agricultural Fund for Rural Development under the measure Rural Development Programme of SR. Additional source was budget of the Nitra Self-governing Region.

Other $22 \%$ of public sources drawn for rural tourism support were used by municipalities $(83.7 \%$ of projects) and non-profit sector (16.3\% of projects) for investment activities focused on construction and reconstruction of tourism infrastructure. These activities should improve the conditions for development of tourism activities in municipalities. It included projects whose implementation should be a benefit for the general public (inhabitants, visitors and enterprises in tourism). Implemented projects were projects that could improve and increase the attractiveness of the municipalities, construction of recreation and relaxation zones in municipalities, public car parks, cyclopaths, rest areas, sport areal, amphitheatres and spatial signs in municipalities. In the area of the NSR 129 projects were implemented with the average amount $39,254 €$ per one project.

Soft projects aimed at rural tourism support in the NSR represented $4.3 \%$ of drawn funds. Projects were mostly aimed at organizing events and revival of traditions in the area, marketing activities, creation of tourism products and promote cooperation in the region. In total, 114 soft projects supporting rural tourism were implemented during the period 2007 - 2015 and the average amount was $8.577 €$ per one project. The funds for soft projects were mostly used by non-profit sector and municipalities, and rarely by entrepreneurs (for marketing support).

\footnotetext{
${ }^{4}$ Facilities of additional services provided within rural tourism supported from public funds in the period $2007-2015$ were mostly horse riding schools, farm buildings, animal parks, relaxation and sport facilities, catering facilities, cellars and facilities for processing and tasting of wine.
} 


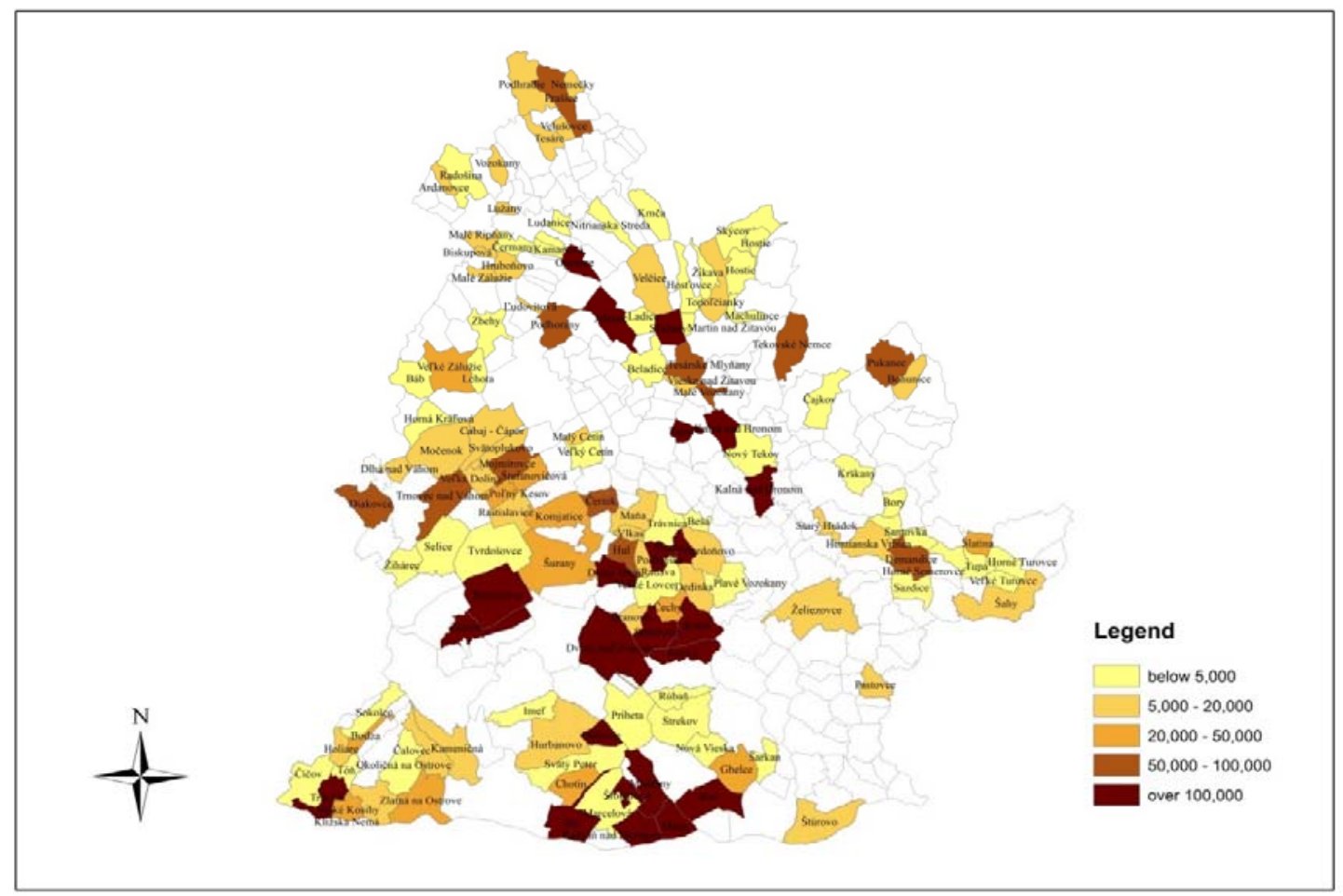

Fig 2. Spatial assessment of public funds spending for rural tourism support in municipalities of the Nitra Selfgoverning Region in 2007-2013 (in €/1000 inhabitants). Source: Own processing using ArcGIS, 2015

\begin{tabular}{|l|c|c|c|c|}
\hline \multicolumn{1}{|c|}{ Project focus } & $\begin{array}{c}\text { Amount of } \\
\text { accounted } \\
\text { subsidy (in €) }\end{array}$ & $\begin{array}{c}\text { \% } \\
\text { share }\end{array}$ & $\begin{array}{c}\text { Number } \\
\text { of } \\
\text { projects }\end{array}$ & $\begin{array}{c}\text { Amount of } \\
\text { NRF/project }\end{array}$ \\
\hline education & 4,163 & 0.02 & 3 & 1,388 \\
\hline $\begin{array}{l}\text { marketing (advertising materials, support of } \\
\text { products sale) }\end{array}$ & 41,691 & 0.18 & 27 & 1,544 \\
\hline $\begin{array}{l}\text { reconstruction of accommodation facilities and } \\
\text { additional services }\end{array}$ & 63,076 & 0.28 & 7 & 9,011 \\
\hline $\begin{array}{l}\text { construction of accommodation facilities and } \\
\text { additional services }\end{array}$ & $16,568,136$ & 72.83 & 75 & 220,908 \\
\hline cooperation (networking, partnership creation) & 12,675 & 0.06 & 8 & 1,584 \\
\hline $\begin{array}{l}\text { protection and management of natural and } \\
\text { cultural sources }\end{array}$ & 72,415 & 0.32 & 24 & 3,017 \\
\hline $\begin{array}{l}\text { construction/reconstruction of infrastructure } \\
\text { (cycling routes tagging, car parks, lay-by, rest } \\
\text { and relaxation areas, sport facilities, } \\
\text { amphitheatre, landing stages, ski tracks, etc.) }\end{array}$ & $5,063,813$ & 22.26 & 129 & 39,254 \\
\hline $\begin{array}{l}\text { creation of tourism products (including creation } \\
\text { of regional products) }\end{array}$ & 657,157 & 2.89 & 15 & 43,810 \\
\hline $\begin{array}{l}\text { management of leisure time (revival of traditions, } \\
\text { organization of leisure events) }\end{array}$ & 262,123 & 1.15 & 61 & 4,297 \\
\hline $\begin{array}{l}\text { reconstruction of agricultural facilities into rural } \\
\text { tourism facilities }\end{array}$ & 2,850 & 0.01 & 1 & 2,850 \\
\hline $\begin{array}{l}\text { construction/reconstruction and modernisation of } \\
\text { facilities focused on production and proceeding } \\
\text { of traditional products (including introduction of } \\
\text { technology) }\end{array}$ & 1,588 & 0.01 & 1 & 1,588 \\
\hline Total NRF -support of rural tourism & $\mathbf{2 2 , 7 4 9 , 6 8 7}$ & $\mathbf{1 0 0}$ & $\mathbf{3 5 1}$ & $\mathbf{6 4 , 8 1 4}$ \\
\hline
\end{tabular}

Tab 3. Overview of the drawn subsidies for rural tourism support in the Nitra Self-governing Region by the project focus in the period 2007 - 2015. Source: own processing, 2015 
In terms of beneficiary for rural tourism development it can be stated that the largest amount of funds was drawn by the private sector $(73 \%)$. In the previous period $(2007-2015) 91$ projects of entrepreneurs were supported in the Nitra Self-governing Region, while one project was supported approximately by the amount $182,817 €$. In the public sector there were supported 137 projects, what represents $25 \%$ of total analysed funds and one project was supported approximately by the amount $42,041 €$. The smallest volume of drawn funds was reached by non-profit sector (1.56\% of the total analysed funds).

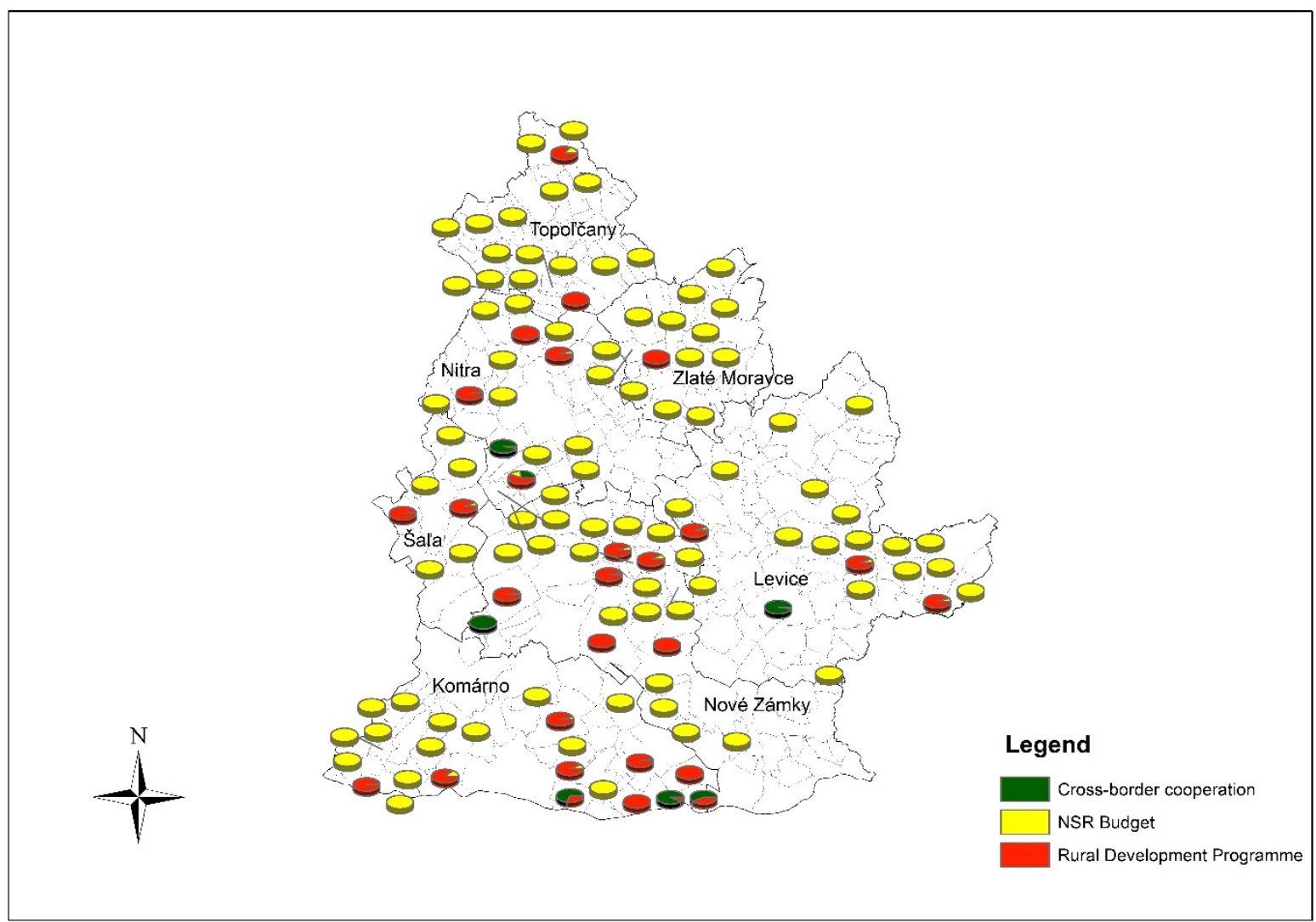

Fig 3. Spatial assessment of public funds spending for rural tourism support in municipalities of Nitra Selfgoverning Region in 2007 - 2013, in terms of source of subsidy. Source: own processing using ArcGIS, 2015

\begin{tabular}{|l|c|c|c|c|}
\hline \multicolumn{1}{|c|}{ Beneficiary } & $\begin{array}{c}\text { Amount of } \\
\text { applied subsidy } \\
\text { (in €) }\end{array}$ & \% share & $\begin{array}{c}\text { Number of } \\
\text { projects }\end{array}$ & $\begin{array}{c}\text { Amount of non- } \\
\text { repayable } \\
\text { grants /project } \\
\text { (in } € \text { ) }\end{array}$ \\
\hline Public sector & $5,759,582.00$ & 25.32 & 137 & $42,041.00$ \\
\hline Private sector & $16,636,339.00$ & 73.13 & 91 & $182,817.00$ \\
\hline Non-profit sector & $353,765.00$ & 1.56 & 123 & $2,876.00$ \\
\hline Total & $22,749,687.00$ & 100.00 & 351 & $64,814.00$ \\
\hline
\end{tabular}

Tab 4. Overview of drawn subsidies for rural tourism support in the Nitra Self-governing Region by beneficiary in the period 2007 - 2015. Source: own processing, 2015

Within the non-profit sector, 123 projects were supported with the subsidy 2,876 $€$ per one project. The amount of drawn funds allocated between particular groups of beneficiaries is closely related to the purpose of the use of funds (investment resp. non-investment projects). Spatial distribution of drawn subsidies by beneficiary in the Nitra Self-governing Region is illustrated in Figure 4. 


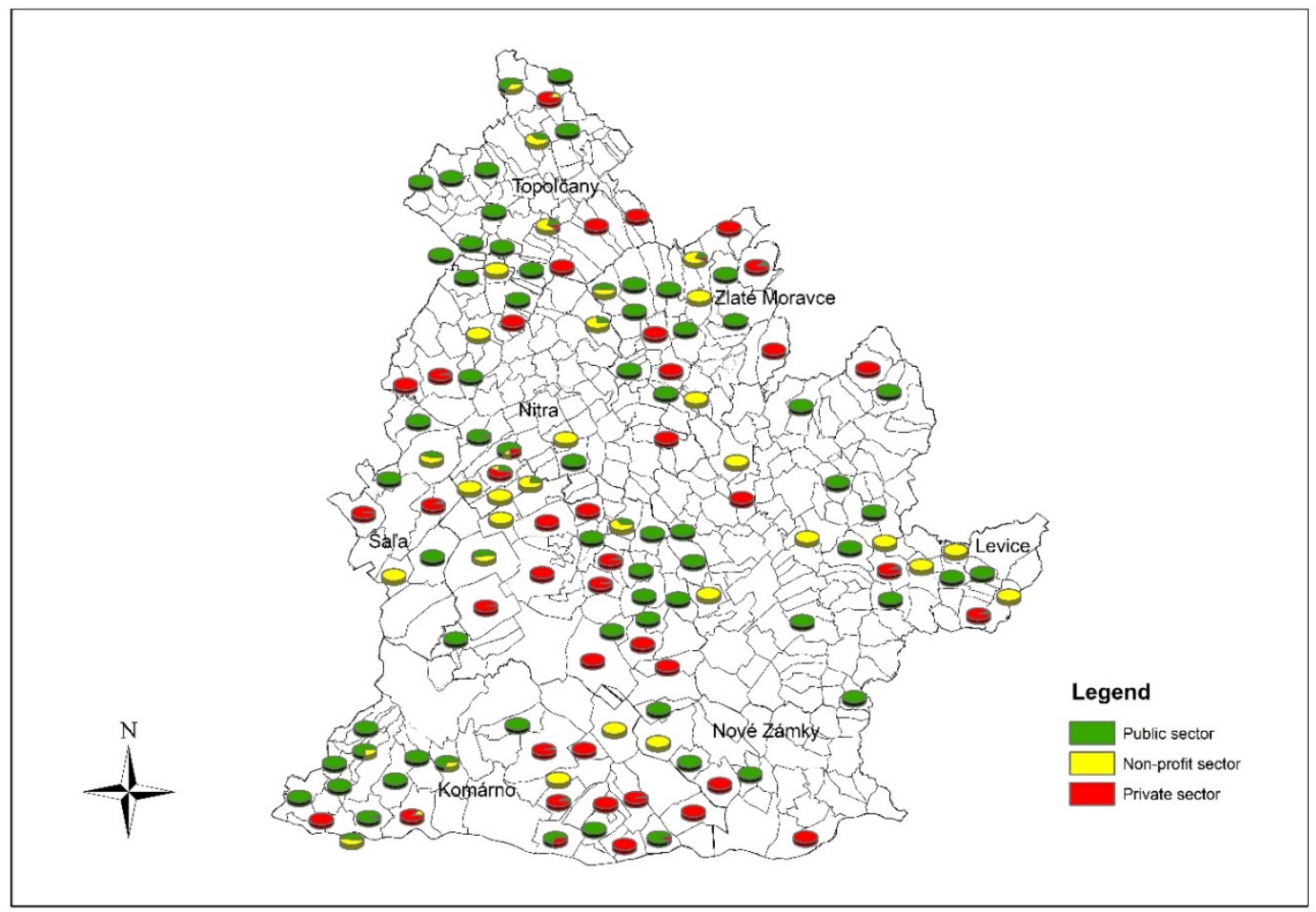

Fig 4. Spatial assessment of public funds spending for rural tourism support in municipalities of the Nitra Selfgoverning Region in 2007 - 2013, in terms of beneficiary. Source: own processing using ArcGIS, 2015

We identified that main sources for funding activities in rural tourism implemented in the Nitra Self-governing Region in the period 2007 - 2015 were financed from: EAFRD (Rural Development Programme), ERDF (cross-border cooperation) and budget of the NSR (tools based on Leader principles). The charts show that in terms of the volume of disposable and drawn subsidies for rural tourism support the most important support was provided by the EU funds, mainly within the Rural Development Programme (73\% of the total amount of funds). The regional sources made up only $3 \%$ of the total amount of funds. Paradoxically, these $3 \%$ supported 269 projects $(77 \%$ of the total number of projects). It shows the interest of beneficiaries in this programme and it also shows the programme as a well set tool of rural tourism support. Subsidies from the NSR were mostly used by municipalities and non-profit sector.
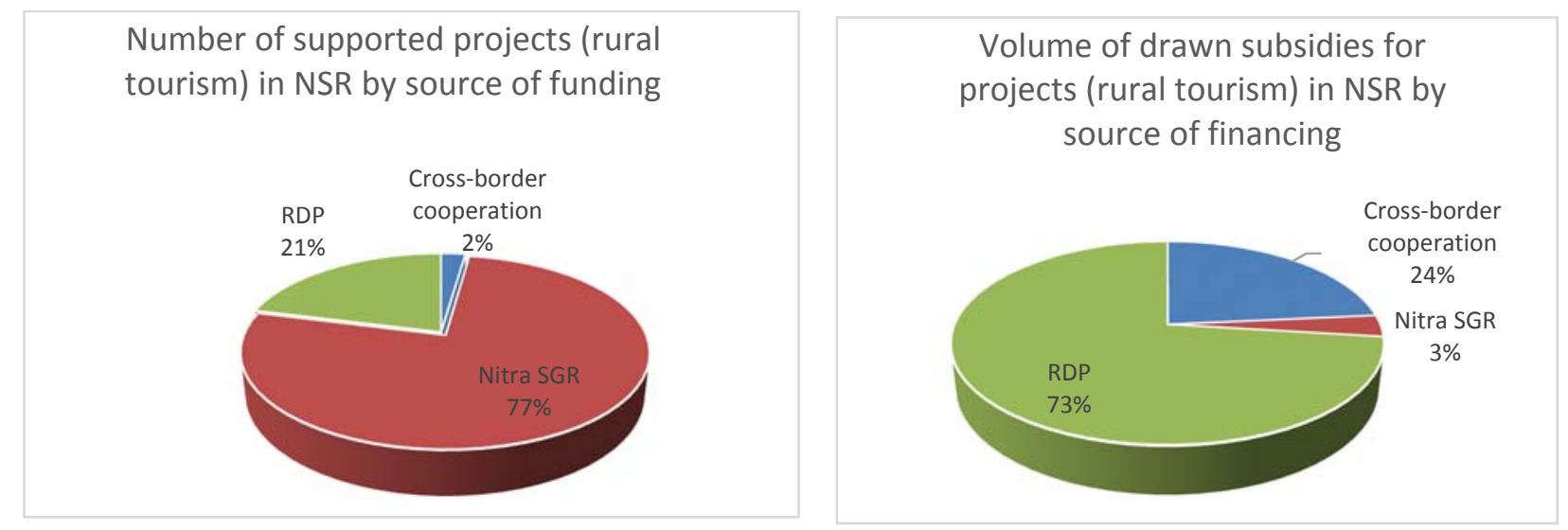

Fig 5. Supported projects. Source: own processing based on data from the Agricultural Paying Agency, Ministry of Agriculture and Rural Development SR and the Office of the Nitra Self-governing Region, 2015 
Impacts associated with the use of public resources in tourism were described also by Baležentis T, Kriščiukaitienè, I., Baležentis A, Garland, R. (2012).

Impact of allocated public funds in the period 2007-2015 on the development of selected indicators in tourism in the NSR can be assessed only partially, as the effects associated with the allocation of resources notably in the investment projects are long term and may occur later. Moreover, the development of tourism in the previous period influenced other external factors that significantly impacted in tourism for example across Europe. The economic crisis has caused a decline in number of visitors, low capacity utilization and a drop in revenues of tourism enterprises. Comprehensive indicator, reflecting on the one hand, the existing capacity of service providers and real demand in the tourism sector on the other hand, is the utilization of bed capacity.

Figure 6 shows the utilization of bed capacity in the Nitra Self-governing Region, which is low (in monitored period it was ranging from $8.8 \%$ - 14.3\%) also according to other regions of SR. The analysed indicator reached the highest value in the year 2008, afterwards it had rather declining or stagnating character. From the data it is evident, that the existing capacity of accommodation facilities in the NSR is not sufficiently used and its utilization has declined after 2008. This situation can be explained, in particular, by the growing supply of accommodation services (as a result of adjustment of financial support) and by the decreasing demand for tourism services due to the economic crisis. In that context, we consider meaningful to direct the funds to activities aimed at enhancing the attractiveness of tourist centres (e.g. complement leisure services for visitors), and to support demand in tourism, not on the basic equipment of tourist resorts by accommodation and catering facilities.

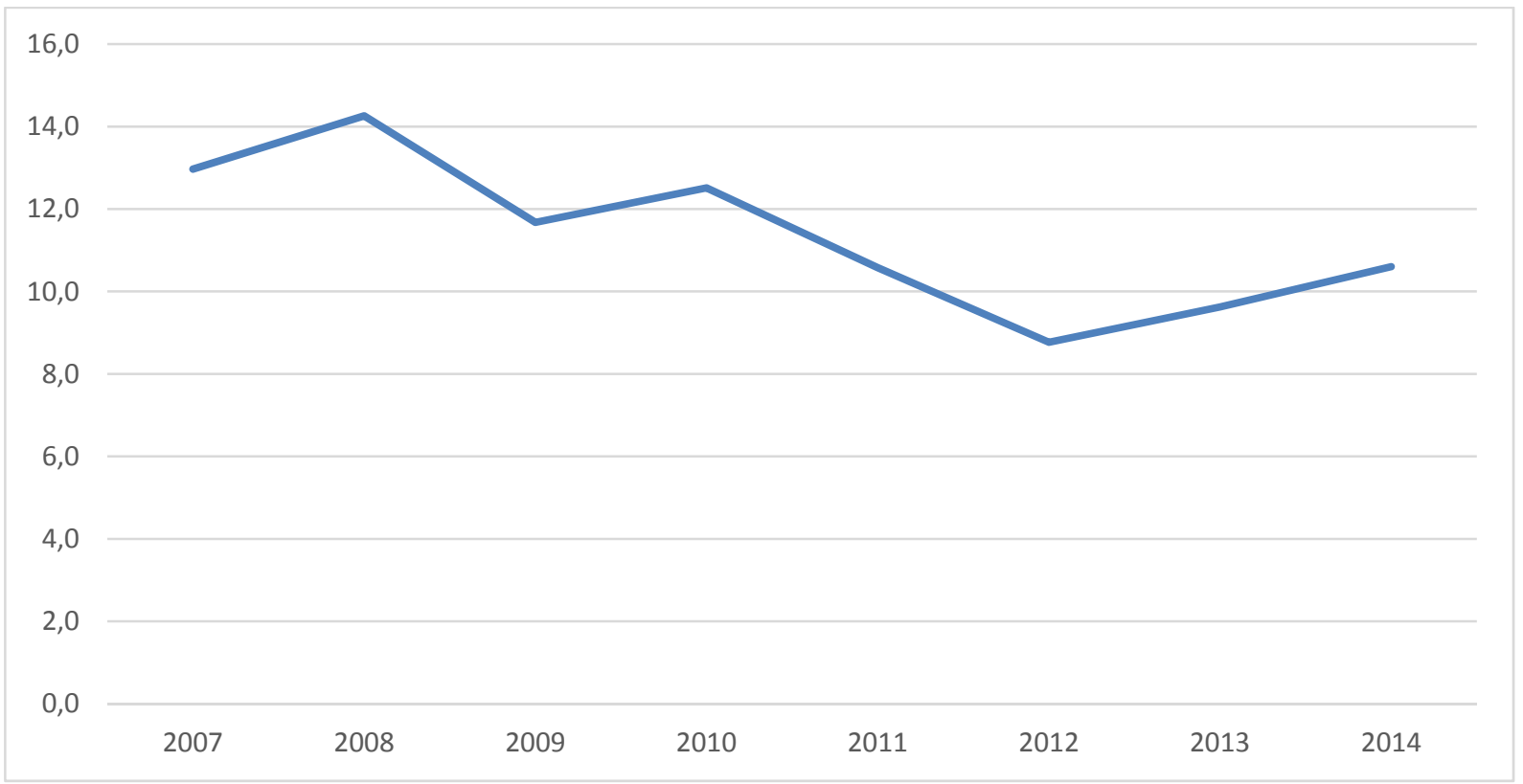

Fig 6. Utilization of bed capacity in the Nitra Self-governing Region in 2007 - 2014 (in \%). Source: own processing based on data from the Statistical Office SR, 2015

\section{Conclusion}

Rural tourism is an economic activity that may contribute to the revival of the rural economy. Being aware of the positive effects derived from the development of this activity in rural areas, rural tourism is supported by financial and non-financial mechanisms at the national, regional and local level. In this paper we researched mainly the use of financial tools to support the development of rural tourism. We found out that in the previous period $2007-2015$ the support of rural tourism was mostly focused on support of investment activities of entrepreneurs $(73 \%$ of monitored sources). Significantly lower volume of funds (only $4.3 \%$ ) was drawn for so called soft projects. These projects aimed at organising events, revival of traditions in the area, marketing, creation of tourism products and promoting of cooperation. In 
the framework of the mechanisms that were used to support rural tourism at the regional level we should highlight subsidy system of the Nitra Self-governing Region. It is a unique example of tool to supplement the lack of funds in the territory and motivated entities which were not interested in EU funds (co-financing, bureaucracy, unauthorized applicant). Despite the fact that the volume of funds from the NSR to project support was lower than the volume of funds from the EU (funds from the NSR represents only $3 \%$ of the total monitored funds), regional budget supported 269 projects aimed at rural tourism ( $77 \%$ of financed projects). This tool was mainly used by municipalities and local action groups. Financial tools for rural tourism support are also going to be used in the current programming period 2014 - 2020. Within the Rural Development Programme SR 2014 - 2020, the support of rural tourism will be aimed at investment activities of entrepreneurs conducting business in the field of primary agriculture production (small enterprises and microenterprises), and public and non-profit sector, again. Municipalities and associations of municipalities will be able to finance construction of tourism infrastructure from the EAFRD. In addition to investment activities, marketing activities of public and non-profit sector and cooperation of tourism entities will be also supported. In the future programming period the support of projects aimed at the field of rural tourism will be supported under crossborder cooperation from the ERDF. Nitra Self-governing Region has added two more subsidy programmes (to existing financial tool based on principles of Leader Programme) focused on support for entrepreneurs operating in tourism and strengthening quality of services of certified accommodation facilities in the rural areas. ${ }^{5}$

\section{Acknowledgement}

The paper was prepared with the support of the Slovak Research and Development Agency under the Contract No. 1/0247/14 Integrated approaches to rural tourism development in conditions of SR.

References

[1] Baležentis, T., Kriščiukaitiene, I., Baležentis, A. \& Garland, R. (2012). Rural tourism development in Lithuania (2003-2010) - A quantitative analysis. Tourism Management Perspectives, 2-3, 1-6. DOI: 10.1016/j.tmp.2012.01.001.

[2] Galvasová, I. et al. (2008). Průmysl cestovního ruchu. Praha: Ministerstvo pro místní rozvoj ČR.

[3] Gučík, M. et al. (2010). Manažment cestovného ruchu. Banská Bystrica: Univerzita Mateja Bela.

[4] Irshad, H. (2010). Rural tourism-an overview. Edmonton: Rural Development Division, Government of Alberta.

[5] Kiper, T. \& Özdemir, G. (2012). Tourism Planning in Rural Areas and Organization Possibilities (p. 123-150). In Ozyavuz, M., ed., Landscape Planning. Rijeka: InTECH.

[6] Lane, B. (1994). Sustainable Rural Tourism Strategies: A Tool for Development and Conservation, Journal of Sustainable Tourism. 2(1-2), 12-18. DOI: 10.1080/09669589409510687.

[7] Maráková, V. (2005). Finančné a nefinančné nástroje podpory podnikania v cestovnom ruchu. Banská Bystrica: Univerzita Mateja Bela.

\footnotetext{
${ }^{5}$ Generally binding regulation No. 13/2015, which changes Generally binding regulation of the Nitra Self-governing Region on granting subsidies from the budget of the Nitra Self-governing Region on tourism support No.5/2015

Generally binding regulation No. 12/2015, which changes Generally binding regulation of the Nitra Self-governing Region on granting subsidies from the budget of the Nitra Self-governing Region on support of certified accommodation facilities in rural areas No. 4/2015
} 
[8] Tej, J. \& Matusikova, D. (2014). Tourism product creation as a basis of economic prosperity of a destination. Економічний часопис-XXI, 5-6, 45-48.

[9] Wokoun, R. \& Mates, R. (2006). Management regionální politiky a reforma veřejné správy. Praha: Linde.

[10] Act No.91/2010 Coll. on support of tourism. 